\title{
Rijal al-Da'wah: Studi Faktor Karismatik Praktisi Dakwah di Kota Bandung
}

\author{
Hajir Tajiri* \\ Fakultas Dakwah dan Komunikasi UIN Sunan Gunung Djati, Bandung \\ *Email:manghajir@gmail.com
}

\begin{abstract}
This study aims to describe charismatic characteristics inherent in some dakwah practitioners in the city of Bandung, which is related to personal quality, efektif communication ability, and social achievement. This research with descriptive method and qualitative approach shows that some of charismatic dakwah practitioners, from the aspect of personal quality generally have good personality integrity characteristic, consistent in holding principle, uphold honesty in message delivery and in their daily life. They also consistent carry out da'wah despite the exam at times come to them. Both epices of communication are characterized by intelligence in choosing words, strategies for initiating communication, using humor as a lecture insert, communication style, and their ability to convey diverse topics. Third, community achievement is characterized by their ability to take advantage of crisis situations in society with intelligent solutions provided. The implication of one's charisma can be built not only one factor but must be integral starting from the personal quality, competence and context of the situation.
\end{abstract}

Keywords: Da'i, Charismatics, Effecitive Communication

\begin{abstract}
ABSTRAK
Penelitian ini mendeskripsikan karakteristik karismatik yang melekat pada beberapa praktisi dakwah di kota Bandung, berkaitan dengan mutu personal, kemampuan komunikasi efektif, serta prestasi kemasyarakatan. Penelitian dengan metode deskriptif dan pendekatan kualitatif ini menunjukkan bahwa beberapa praktisi dakwah yang tergolong karismatik itu pertama, dari aspek mutu personal umumnya memiliki ciri integritas kepribadian yang baik, konsisten dalam memegang prinsip, menjunjung tinggi kejujuran dalam penyampaian pesan maupun dalam hidup kesehariannya. Mereka juga istiqomah menjalankan dakwah kendati ujian sewaktu-waktu datang menimpa mereka. Kedua, kemampuan komunikasi efektif ditandai dengan kecerdasan dalam memilih kata, strategi mengawali komunikasi, penggunaan humor sebagai sisipan ceramah, gaya komunikasi, serta kemampuan dalam menyampaikan topik yang beragam. Ketiga, prestasi kemasyarakatan ditandai dengan kemampuan memanfaatkan situasi krisis di masyarakat dengan solusi-solusi cerdas yang diberikan. Implikasinya karisma seseorang dapat terbangun tidak hanya satu faktor saja melainkan harus integral mulai dari mutu personal, kompetensi dan konteks situasi.
\end{abstract}

Kata Kunci: Da’i, Karismatik; Komunikasi Efektif

\footnotetext{
* Tulisan ini pernah dipresentasikan di Seminar Nasional Dakwah, Bandung, 27-29 Oktober 2018
} 


\section{PENDAHULUAN}

Keberadaan da'i (rijal al-da'wah)di tengah masyarakat yang sedang membangun sangat dibutuhkan. Peran dan fungsi da'i sebagaimana disebutkan oleh Amin Abdullah (dalam Rifanudin, 2007) antara lain sebagai penyeru (munadi), pendidik (muaddib), pemersatu (muwabhid), pelurus informasi (musaddid) dan pembaru (mujaddid), berkontribusi terhadap terciptanya suasana masyarakat yang sedang melangsungkan pembangunan sehingga terbuka jalan dalam menggapai kebahagiaan dan kesejahteraan.

Namun demikian, tidak semua da'i mampu secara nyata memberikan kontribusi bagi kemajuan dan kebahagian umat manusia tersebut. Dari jumlah da’i yang mencapai ribuan, mungkin tidak akan mencapai 10\% yang kontribusinya dapat dirasakan dan diterima secara eklusif oleh masyarakat. Dalam istilah atau pernyataan seorang sosok cendekiawan muslim di Jawa Barat, Nanat Fatah Natsir, ada da'i yang diminati dan yang tidak diminati, ada da'i yang pintar diminati, ada yang kurang pintar tapi diminati, ada juga yang kurang pintar tapi tidak diminati. Kyai-kyai pesantren itu ilmunya tinggi tapi kurang diminati, sebaliknya orang baru tampil atau muncul langsung diminati.

Sosok da’i yang diterima secara ekslusif biasanya memiliki karakteristik unggul, terampil, dapat dipercaya. Mereka memiliki pengaruh yang dalam dan tidak biasa pada pengikut. Para pengikut merasa bahwa keyakinan dan praktik keagamaan tokoh yang diidolakan adalah benar, mereka bersedia mengikuti himbauan maupun ajaran yang dibawa oleh tokoh yang diidolakannya itu, mereka mencurahkan rasa kasih sayang, penghormatan, cinta dan kesetiaan terhadap tokoh idolanya. Secara emosional mereka terlibat dalam misi yang sedang diusung dan diperjuangkan oleh tokoh idolanya.

Dalam pandangan para pengikut sosok da'i tersebut dipandang memiliki kemampuan mengekspresikan suatu pandangan, keyakinan dari ajaran agama yang dipilihnya, pemberi solusi atas situasi yang carut marut, berbagai kekacauan dan kebimbangan dengan cara yang tepat dan sangat menarik. Para tokoh itu muncul dengan pribadi yang memiliki rasa percaya diri luar biasa, mempunyai visi dan mampu mengungkapkannya secara nyata, tidak terikat oleh aturan tertentu, mempunyai keterampilan komunikasi yang hebat, serta bersedia melakukan pengorbanan diri dan sanggup mennanggung resiko.

Profil da'i sebagaimana dijelaskan karakteristiknya, bukan hanya bernilai karena kemampuan komunikasi yang memikat, tetapi juga karakteristik kepribadian. Sosok seperti ini mampu memadukan antara ucapan dan perbuatan. Sosok yang bukan hanya piawai menyampaikan tetapi juga terampil mengamalkan. Sosok seperti itu bukan hanya cerdas secara intelektual tapi juga cerdas secara emosional, sosial dan spiritual.

Secara teoretik daya penerimaan (acceptability) seseorang dapat diakui manakala ada kesaksian sekelompok manusia yang mencintai, mengagumi, 
menghormati dan lebih jauhnya berkesiapan mematuhi dan mengikuti ajakan tokoh tertentu. Kriteria tersebut tidak hanya diukur karena kelantangan suaranya, tinggi atau besarnya tubuh seseorang, dan apalagi ketampanan atau warna kulit, tetapi seberapa daya penerimaan masyarakat terhadap daya tarik kualitas personal (personal quality), kemampuan komunikasi (competence) dan konteks situasi (situation context). Daya tarik kualitas personal misalnya ditunjukkan dengan integritas, konsistensi, kejujuran (akhlak dan/kepribadian). Kemampuan komunikasi efektif ditunjukkan dengan artikulasi konsep dan gagasan dalam sebuah cara yang memberikan insfirasi dan motivasi. Sedangkan prestasi dalam situasi krisis (situation context)di tengah masyarakat ditunjukkan dengan pemberian solusi atas masalah keagamaan di tengah masyarakat. Hal ini sebagaimana dijelaskan Robert House tentang teori karismatik (Jennifer L. Efley, 2015), Keberadaan seorang pemimpin(da'i) karismatik memiliki pengaruh luar biasa terhadap pengikut, bukan karena tradisi atau otoritas tapi karena persepsi pengikut; ia tampil sebagai model peran dan panutan hidup; Ia memiliki percaya diri yang luar biasa, mempunyai visi, dan mampu mengungkapkan visi secara gamblang, mempunyai keterampilan komunikasi yang hebat, bersedia membuat pengorbanan diri, mengambil resiko pribadi. Keberadaannya sangat dihormati, dihargai, dicintai, dipatuhi, dan mereka sangat setia dan berpengharapan tinggi terhadap kehadirannya.

Berdasarkan teori di atas, ada beberapa tipikal da'i di Bandung yang menarik dicermati saat ini. Beberapa da'i tersebut diantaranya KH. Miftah Faridl, KH. Abdullah Gymnastiar dan Ustadz H. Aam Amirudin. Mereka pantas dijuluki sebagai da'i berkarisma. Bukti-bukti yang menunjukkan mereka berkarisma, ketika tiap kali mereka ceramah, maka aktivitas ceramah (dakwahnya) dihadiri oleh banyak mustami' atau pengunjung, kepada sosok para da'i tersebut banyak orang yang mau berkonsultasi serta mendapatkan kepuasan dari jawaban para ustadz atau kyai itu. Selain itu masyarakat juga kagum dengan prestasi dan kemampuan yang mereka miliki.

Berkait dengan ini ada beberapa penelitian yang relevan. Penelitian Bambang Saiful Ma'arif, Haris Hasbullah dan Seviyenti Fikroh (2011), menyebutkan bahwa sosok seperti H. Aam Amirudin memiliki jama'ah yang dalam setiap acara pengajian dengan jumlah yang konstan, dapat mencapai ratusan atau ribuan orang. Demikian juga dengan KH. Abdullah Gymnastiar apalagi beliau sempat menjadi figure da'i nasional dan dakwahnya disaksikan oleh banyak orang, Bagaimanakah ketiga sosok tokoh dakwah ini jika dilihat berdasarkan teori karismatik?

Penelitian ini bertujuan mendeskripsikan karakteristik karismatik yang melekat pada beberapa praktisi dakwah di kota Bandung, yaitu berkait dengan mutu personal, kemampuan komunikasi efektif, serta prestasi kemasyarakatan yang melekat pada beberapa praktisi dakwah di Kota Bandung.

Penelitian menggunakan metode deskriptif dalam pendekatan kualitatif. Dalam metode deskriptif, peneliti membandingkan fenomena-fenomena tertentu 
sehingga merupakan suatu studi komparatif. Metode ini mengambil bentuk kegiatan membandingkan segi-segi atau aspek-aspek yang melekat pada dua unsur atau lebih yang diperbandingkan. Menurut Acep Aripudin dan Mudhofir Abdullah (2015) dalam studi banding yang harus dibandingkan pertama dan utama adalah pertama, apa yang dibandingkan mesti setara pada setiap unsur dakwah sebagai alat pembanding. Kedua, pembanding mesti mengetahui dua atau lebih objek atau persoalan yang akan dibandingkan. Ketiga, Pembanding mesti memiliki maksud dan tujuan dari pembandingannya.

\section{HASIL DAN PEMBAHASAN}

Tegaknya dakwah bergantung pada masih adanya para pelaku, pemangku, pengemban amanah yang agung ini yaitu para da'i yang memiliki i'tikad baik untuk kemaslahatan dan kelangsungan hidup manusia di dunia. Mereka tidak pernah bosan untuk terus berdakwah memperbanyak jumlah orang-orang yang shaleh di dunia. Mereka menyadari betul bahwa dunia ini diwariskan untuk orang-orang yang shaleh. Karena itu terus berusaha untuk meningkatkan kualitas keberagamaan masyarakat dakwah, yakni kualitas aqidah, ibadah dan akhlak/budi pekerti.

Tampaknya seperti itu pula sepak terjang para da'i yang ada di kota Bandung. Sederet nama telah menghiasi bumi kota Bandung dengan sinar dan pancaran ilmu dan keshalehannyam antara lain KH. Abdullah Gymnastiar, KH. Aam Amirudin dan KH. Miftah Faridh. Mereka dapat disebut tokoh dakwah yang memiliki kemampuan luar biasa dalam hal pemahaman agama (tafaqquh fid-din) dan juga pemahaman metodologis (tafaqquh fin-nas). Pemahaman agama ditunjukkan dengan kesiapannya untuk berbicara tentang agama dalam beragam topik termasuk sumbangsih pikirannya ketika harus berpolemik atau mengemukakan pandangan berkait dengan isu-isu yang berkembang di masyarakat. Agama bukan sekedar materi yang harus disampaikan tetapi bagi mereka agama juga dapat digunakan sebagai perspektif. Bagaimana mereka merespons dan mensolusi masalah berdasarkan perspektif agama. Pada wilayah ini mereka memiliki ciri karakteristik kemampuan dalam hal konteks situasi (situation context).

Berikut ini akan diurai bagaimana profil tokoh da'i di Kota Bandung ini terkait dengan beberapa karakteristik karismatik seperti mutu personal (personal quality), kemampuan komunikasi efektif dan prestasi kemasyarakatan/keumatan (situation context).

\section{Kualitas Pribadi (Personal Quality)}

Berdasarkan teori karismatik, mutu pribadi merupakan sebagian dari penentu diterimanya sosok pendakwah oleh masyarakat. Menurut Bambang S. Ma'arif (2009: 164), mutu pribadi termasuk pada kriteria etis yang dapat meningkatkan daya kekuatan sebagai figur. Kualitas pribadi dapat dilihat berdasarkan fakta-fakta empirik berkait dengan integritas, kejujuran, konsistensi, keberanian, tanggung 
jawab. Ini sejalan dengan konsep personal quality dari Efley (2015), sehingga ketiga tokoh dapat digambarkan dalam tabel sebagai berikut:

Tabel 1 Mutu Pribadi

\begin{tabular}{|c|c|c|c|}
\hline Da'i & Integrity & Honesty & Consistency \\
\hline $\begin{array}{l}\text { KH. Miftah } \\
\text { Faridl }\end{array}$ & $\begin{array}{l}\text { Belum pernah } \\
\text { terdengar baik gossip } \\
\text { maupun fakta yang } \\
\text { membuat dirinya } \\
\text { tergelincir }\end{array}$ & $\begin{array}{c}\text { Beberapa } \\
\text { kepercayaan yang } \\
\text { diterima dari } \\
\text { masyarakat seperti } \\
\text { menjadi Ketua MUI, }\end{array}$ & $\begin{array}{l}\text { Karir dakwah tidak } \\
\text { pernah terhenti }\end{array}$ \\
\hline $\begin{array}{c}\text { KH. } \\
\text { Abdullah } \\
\text { Gymnastiar }\end{array}$ & $\begin{array}{c}\text { Sifatnya yang lembut, } \\
\text { dan terkesan } \\
\text { mempertim } \\
\text { bangkan perasaan } \\
\text { seakan terusik menjadi } \\
\text { raja tega terutama oleh } \\
\text { kalangan wanita yang } \\
\text { tidak menginginkan } \\
\text { hidupnya didua }\end{array}$ & $\begin{array}{l}\text { Mengalirnya berbagai } \\
\text { bantuan untuk } \\
\text { kemajuan yayasan } \\
\text { darut-tauhid terutama } \\
\text { sebelum mengalami } \\
\text { goncangan karena } \\
\text { badai poligami }\end{array}$ & $\begin{array}{l}\text { Karir dakwah sempat } \\
\text { tergoncang karena } \\
\text { poligami }\end{array}$ \\
\hline $\begin{array}{l}\text { Ust. H. Aam } \\
\text { Amirudin }\end{array}$ & $\begin{array}{l}\text { Nilai-nilai agama yang } \\
\text { pernah ditekuninya } \\
\text { masih tetap terjaga dan } \\
\text { terpelihara walau harus } \\
\text { menerima tuntutan gaya } \\
\text { hidup baru }\end{array}$ & $\begin{array}{l}\text { Jadwal ceramah yang } \\
\text { semakin bertambah } \\
\text { bukan hanya dari } \\
\text { mesjid ke mesjid tapi } \\
\text { juga oleh stasiun } \\
\text { televisi }\end{array}$ & $\begin{array}{l}\text { Karir dakwah masih } \\
\text { tetap berlangsung }\end{array}$ \\
\hline
\end{tabular}

Tabel 1 menggambarkan, Pertama, KH. Miftah Faridl. Kyai Miftah itu sosok pribadi yang utuh dan sempurna. Jika dilihat berdasarkan teori front stage dan back stage Erving Goffman (Mega Augustia, 2016), ia bukan sosok yang senang bermain muka, kepribadian beliau itu bukan kepribadian topeng, yang hanya bagus ketika disaksikan orang. Sosok beliau ini tampak bagus di depan dan belakang, bukan hanya bagus karena tuntutan profesi harus menyampaikan pesan kebenaran, tapi pesan itu diyakininya serta diamalkannya, sehingga apa yang diucapkan itulah cermin kepribadiannya, dan sebaliknya pesan yang beliau sampaikan adalah sesuatu yang utuh, tidak dikurangi karena umat akan berat melakukannya, tetapi apa yang benar dari ajaran Islam ia akan sampaikan sepenuhnya.

Karakternya yang kuat tampak pada konsistensinya dan tidak mudah terpengaruh pihak lain dalam hal prinsip. KH. Miftah Faridl jarang menolak jika ia diminta berdakwah; merupakan sosok da'i terkenal, namun demikian beliau tidak pernah memasang tarif dalam berdakwahnya bahkan ia pernah diberi amplop kosong dalam dakwahnya namun ia selalu berpikiran positif seraya berkata mungkin saja ada kesalahan dalam pemberian amplop, merefleksikan ciri konsistensi (Efley, 2015).

Dalam penampilan, sosok Miftah Faridh tidak mengenakan pakaian yang 
tidak lazim, jas dan kopeah serta celana panjang dengan warna tidak mencolok seperti abu atau hitam. Terkadang beliau memandang cukup walau hanya dengan baju koko putih. Cermin presentasi diri yang baik dengan kesederhanaannya (Efley, 2015). Ia juga yang bersahaja, gaya tuturnya menyejukkan, dan tidak pernah meledak-ledak dalam menyapaikan ceramahnya, tenang, santun, tampak pancaran spiritual dari raut wajah dan perilakunya.

Presentasi diri juga tampak ketika KH. Miftah merespon berbagai peristiwa yang menimpa umat Islam, serta pandangannya terhadap tindakan yang ditempuh sebagian umat Islam sebagai bentuk respons terhadap penistaan Nabi Saw oleh pihak yang tidak menyenanginya. Hal ini seperti komentar beliau tentang karikatur yang menghina Rasulullah Saw oleh Harian Denmark Jylland Posten serta reaksi sebagian umat Islam. Beliau berkomentar, “

Dalam Alquran memang tidak ada ayat yang melarang secara khusus menggambarkan sosok Nabi Saw, namun para ulama sepakat, sosok beliau tidak boleh digambarkan. Ini tidak berdasarkan Alquran melainkan ijtihad para ulama, dan kalau para ulama sepakat seluruhnya, ini menjadi sumber hukum dalam Islam.

Kedua, KH. Abdullah Gymnastiar. Tipikal Aa Gym tidak mancla-mencle dalam hal keagamaan, teguh pada prinsip, mempertahankan kesantunan, dan jika harus marah, ia marah sesuai tempatnya, mempertahankan kebenaran dan tidak lari dari permasalahan hidup. Gambaran detil bagaimana kepribadian/integritas Aa Gym dapat ditelusuri dari pesan-pesan nasihatnya dalam ceramah.

Tampaknya tidak diragukan dalam perjalanan hidupnya sosok Aa Gym merupakan sosok yang konsisten. Hingga kini Ia konsisten dalam memilih tugas hidup sebagai pendakwah, kendati badai hidup yang disebabkan oleh pilihan untuk poligami sempat membuat banyak jama'ah terutama kaum Hawa sempat berpaling ke lain hati, berubah dari cinta menjadi kurang simpati terhadap Aa Gym. Namun demikian hingga kini semangat Aa Gym tetap tidak berubah. Ia hanya mencoba mencari hikmah dari peristiwa yang pernah dialaminya.

Bagi Aa Gym, segala sesuatu tidak ada yang dirahasiahkan sepanjang hal tersebut untuk kebenaran. Berbagai penerimaan dan keuntungan bisnis penghitungannya dilakukan secara transfaran dan modern. Ia juga tidak suka menyembunyikan ilmu, berbagai kegiatan oengajian terus beliau laksanakan baik menghadiri pengundang atau ia berdakwah di tempatnya sendiri masjid Tauhid.

Presentasi diri dilakukan dalam upaya memelihara hubungan kepercayaan antara da'i dengan jama'ah atau umat. Upaya-upaya yang dilakukan mulai dari tampilan diri untuk tetap menarik, unik dan nyentrik. Yaitu busana bersorban seperti Pangeran Diponegoro. Apapun jenis pakaian seperti baju koko, batik, stelan jas dan sarung, jubah putih, maka Aa Gym tetap tidak akan melepaskan sorbannya. Kecuali dalam even seminar atau kajian maka ia cukup mengenakan stelan jas.

Dalam berkarakter dan berkepribadian ia mempopulerkan dan mengamalkan konsep 5 S: Senyum, Salam, Sapa, Sopan dan Santun. Ia juga 
menawarkan $3 \mathrm{M}$ : Mulai dari diri sendiri, mulai yang kecil-kecil dan mulai saat ini.

Ketiga, KH. Aam Amiruddin. Penggunaan istilah-istilah yang berkait dengan pesan keagamaan, ilustrasi yang tersambung dengan kisah dan perjalanan nabi serta para sahabatnya, hukum-hukum al-Qur'an, kemampuan menafsir dan menggali pemahaman yang menunjukkan kepemilikan ilmu alat serta kecerdasan, ini menunjukkan kompetensinya yang memadai dalam pengetahuan dan wawasan. Kemudian keunikan beliau mampu mengintegrasikan ilmu social modern dengan agama menunjukkan bahwa beliau bukan hanya pandai secara teori tapi juga aplikasi atau penerapannya dalam dakwah sehingga dakwah yang ditampilkannya terasa modern dan terpelajar.

Pribadi Aam Amirudin merupakan sosok da'i dengan penampilan sederhana. Kadang beliau ceramah cukup dengan mengenakan baju koko dan tanpa sorban dan kopeah. Setiap kali ada permintaan ceramah sepanjang tidak bentrok dengan jadwal yang lebih dahulu, beliau selalu menyanggupinya. Namun demikian beliau selalu tampak percaya diri dengan kemampuan yang dimilikinya.

Beliau cukup amanah dalam menjalankan kepercayaan. Beliau sering berhadapan dengan jama'ah di Percikan Iman. Beliau meyakinkan jama'ahnya dengan ucapan dan perilakunya. Apabila harus ceramah maka bacaan al-Qur'an dan sunnah Nabi Saw., senantiasa beliau sertakan sebagai unsure pokok nasihat sehingga terasa kedalaman dan bobot ajaran yang disampaikan.

Sejak usia muda hingga kini beliau tidak pernah menghentikan kegiatan dakwahnya. Dakwah yang beliau tekuni bukan hanya ceramah (tabligh), tetapi juga pembinaan intensif seperti bimbingan manasik haji serta pembimbingan jama'ah haji (irsyâd). Selain itu ia juga aktif mengelola yayasan Percikan Iman serta KBIH. Beliau juga cukup konsisten mengelola yayasan percikan iman yang telah didirikannya puluhan tahun yang lalu, penerbitan majalah da'wah serta melangsungkan kegiatan pengajian. Melalui yayasan yang didirikannya, ia juga mengembangkan pelayanan ibadah haji dan umroh.

Beliau memiliki pribadi yang amanah. KBIH yang ia kelola cukup berkelas, dimana pelayanan jama'ah haji dilakukan sesempurna mungkin dan memiliki cita rasa berkelas, pelayanan hotel berbintang lima serta pelayanan ibadah secara prima. Beliau juga dipercaya jama'ah dalam hal mengawal prinsip ajaran agama serta kemampuan menjelaskan agama secara benar dan dapat dipertanggungjawabkan.

Style beliau begitu sederhana, tidak banyak motif di dalam bajunya yang menunjukkan bahwa beliau adalah seorang penceramah yang sudah banyak di kenal orang. Kepribadian yang sederhana ini lah yang membuat beliau sangat banyak di sukai oleh para jamaah di khususnya di daerah Bandung.

\section{Kemampuan Berkomunikasi dengan Baik}

Kemampuan komunikasi efektif mencakup retorika, sentuhan emosional dalam retorika, penggunaan dramatic, symbolik, dan bahasa metaforik (Efley, 2015). Ideide, pikiran-pikiran dan konsep-konsep yang diartikulasikan dalam sebuah cara 
memberikan insfirasi dan memotivasi. Retorika sebagaimana dikatakan Hendrikus dalam Bambang S. Ma'arif (2015) merupakan perpaduan bakat alam dan keterampilan teknik pada diri seseorang. Kemampuan komunikasi ketiga tokoh dapat digambarkan sebagai berikut;

KH.Miftah Faridl. Karakteristik unik yang dimilikinya bahwa dakwah beliau itu retorik (menggunakan retorika), sangat Stragel, futuristic, academik dan sentuhannya itu merefleksikan sentuhan Qur'ani dan Haditsi atau Sunnati Rasuli, apresiatif, manusiawi, menekankan pentingnya Idkholu Surur dan akhlakul karimah.

Kemampuan komunikasi dakwah kyai Miftah itu sangat luar biasa, tampaknya sulit mencari tokoh lain seperti Kyai Miftah. Tokoh lain mungkin memiliki kemampuan metodologis dalam lapangan keilmuan tapi dari segi kedalaman ilmu tidak akan seperti Kyai Miftah. Beliau itu sosok yang fenomenal, ceramahnya sistematis, dan sangat menguasai.

Dijelaskan oleh seseorang yang dekat dengan beliau, dan juga seorang jama'ah di Yayasan As-Sakur, retorika Kyai Miftah itu sangat bagus, beliau pandai sekali mengemas pesan ceramah. Kepandaian beliau itu menyesuaikan dengan tujuan dakwah yang dilakukan. Jika dakwah itu dalam rangka muhasabah seperti muhasabah akhir tahun atau pergantian tahun, dan beliau menargetkan membuat hadirin menangis atas sentuhan qalbu yang beliau terapkan maka, hadirin betulbetul menangis, juga kalau beliau bermaksud membuat orang tersenyum maka jama'ah yang didakwahinya betul-betul dapat menikmati senyuman.

Jika mendengarkan ceramah-ceramahnya baik langsung maupun melalui media seperti radio, tape recorder dan televisi, tampak ada keunikan retorika pada ceramah yang dilakukan oleh Miftah Faridh. Variasi nada (intonasi) seperti ada walaupun itu tidak meledak-ledak. Sekilas seperti datar tapi sesungguhnya pada pesan tertentu ia menyampaikannya dengan nada yang tinggi. Seperti nada emosional sahabat ketika nabi Saw diperlakukan kasar oleh kaum musyriqin Quraish, atau ketika Nabi Saw dakwah di Thaif dilempari dengan batu, maka intonasi dari perkataan sahabat itu begitu tinggi. Nada tinggi juga kadang ia lakukan jika ia menyampaikan sesuatu yang perlu diperhatikan dan dianggap penting seperti dalam nasihat kepada pasangan yang baru nikah.

Gaya komunikasi yang dimiliki KH. Miftah Faridl merupakan gaya komunikasi yang menyesuaikan dengan sasaran. Gaya komunikasi seperti ini menurut Bayu Nitin Pratiwi (2017) merefleksikan penggunaan karakter gaya komunikasi antara lain: the controlling style, the equalitarian style, the structuring style, the dynamic style, the relinquishing style dan the withdrawal style.

Gaya komunikasi konteks rendah ditandai dengan pola pikir linier, sehingga berbicara secara linier pula, ditandai dengan sifat langsung, lugas, dan eksplisit (Deddy Mulyana, 2008). Contoh pernyataan beliau tentang ketentuan dzikir, menurut beliau dzikir itu sedapat mungkin dilakukan sesuai syar'i yang dicontohkan oleh Rasulullah yaitu membaca subhanallah 33 kali, Alhamdulillah 33 
kali, Allahu Akbar 33 kali dan ditutup dengan lailaha illallah. Ini harus diutamakan setiap ba'da shalat, baru setelah do'a jika ingin menunaikan dengan jumlah 1000 tidak dilarang. Yang pokok melakukan sesuai sunnah, tentu ada hikmah dibalik penetapan jumlah itu.

Baik dan buruknya tampilan dakwah (ceramah) seseorang biasanya sudah tampak pada saat awal bicara, apa yang pertama kali ia sampaikan saat memulai ceramah. Demikian juga dengan KH. Miftah Faridl, beliau biasanya tidak berteletele dalam kalimat pembuka seperti ungkapan syukur, sedangkan ketika memulai bicara, beliau memiliki pola yang variatif, terkadang beliau suka langsung menyebutkan topik yang diikuti dengan pembahasan/uraian. Tapi pada kesempatan lain, ia mengawalinya dengan gagasan besar yang berhubungan dengan topik sebagai prolog, adakalanya inti gagasan diambil secara langsung dari kesimpulan pribadi KH. Miftah Faridl sendiri tentang sebuah fenomena yang inti gagasannya mencakup keseluruhan uraian. atau diturunkan dari al-Qur'an.

Terkadang beliau mengawalinya dengan kisah yang relevan dengan topik. Pada kesempatan lain, terkadang beliau suka langsung ke pembahasan. Terkadang KH. Miftah mengawali ceramah sebagai prolog dengan gagasan besar berkenaan dengan topik. Terkadang pada kesempatan lain di ceramahnya ia awali dengan do'a yang relevan dengan topic.

Untuk membuat tampilan lebih menggugah maka beliau akan mencari bahan penyampaian yang mengandung daya tarik perhatian, misalnya mengangkat isu atau contoh dari tokoh fenomenal. Beliau mempunyai strategi untuk menjaga tingkat perhatian jama'ah antara lain dengan teknik humor, ada saja di sela-sela ceramah itu sisipan yang mengandung jenaka. Sisipan jenaka itu umumnya untuk menjaga agar jama'ah tidak berkurang daya konsentrasinya. Namun beliau juga tetap berupaya untuk menjaga prinsip agar jama'ah tidak buyar, materi tetap fokus dan serius. Sisipan humor tidak konyol hingga materi yang sesungguhnya serius tidak menjadi tidak bernilai lantaran membuat cemoohan.

Humor yang terkesan banyolan berisi nada kritik atas perilaku yang kurang pantas. Penempatannya dilakukan ketika beliau berbicara tentang konsep ideal cinta seperti dimiliki dan dipraktikan Robi’ah Adawiyah yang telah mampu menggeser dan mengorbankan cinta-cinta lain selain Allah. Ilustrasi tentang perilaku yang tergerakan atas dasar cinta seperti seorang mendengar suara adzan,

Ceramah beliau juga memiliki ciri berupaya meningkatkan minat dan perhatian melalui informasi baru yang ada relevansi dengan isu topik yang dibicarakan.

KH. Abdullah Gymnastiar. Retorika Aa Gym itu baik tapi bukan pada volume suaranya, melainkan bobot pemaparan atau isi penyampaiannya yang mendalam. Beliau itu seakan bank informasi/pesan spiritual yang berjalan. Kalau sudah ceramah maka banyak hal berupa pengalaman hikmah, ilmu, peristiwa, kisah yang dapat beliau sampaikan. Ceramah beliau rata-rata bisa lebih dari satu jam dan beliau berbicara tanpa henti, tapi dari uraian demi uraiannya enak dinikmati dan 
penasran untuk terus menyimak isi ceramah yang beliau sampaikan.

Bahasa tausiyah Aa Gym gampang dipahami, Ia membahasakan rencana konsep dalam Al-Qur'an ke bahasa yang gampang dipahami oleh audiensnya. Umpamanya, rencana tazkiyatun-nafs diuraikan lebih simpel. Jadi utamanya melindungi keikhlasan, meluruskan kemauan, serta melaksanakan ibadah hanya Cuma mengharap rido Allah.

Aa Gym juga memilih bahasa keseharian hingga tausiyahnya dapat diterima oleh audiens yang umumnya ibu-ibu rumah tangga. Aksen sunda dalam bicaranya juga membuat kedekatan dengan orang-orang Jawa Barat yang teratur mengikuti pengajiannya setiap minggu di Darut Tauhid.

Tausiyah Aa Gym dikemas sedemikian rupa supaya gampang diolah serta diingat oleh audiensnya. Satu diantara langkah yang dikerjakan Aa Gym yaitu memakai singkatan. satu diantaranya jargon singkatan yang popular yaitu 3M: mulai diri sendiri, mulai hal kecil, mulai saat ini. Singkatan 3M ini lalu diadopsi oleh beragam kelompok untuk kampanye atau mungkin lakukan pengertian yang riil, seperti pemberantasan demam berdarah. Singkatan-singkatan tidak sering dipakai ulama lain hingga jadi ciri khas tausiyah Aa Gym.

Aa Gym juga sering memberi missal pengalaman riil dirinya atau orang lain terkait dengan topik ceramahnya. Misal tingkah laku dijadikan tausiyah Aa Gym seperti dongeng yang sangat menghibur sekaligus ide. Umpamanya, bagaimana ia mengatur waktu untuk penuhi kewajibannya juga sebagai bapak serta suami diantara beragam kesibukkannya.

Sebagian besar ustadz atau penceramah mengangkat tema-tema sekitar ubudiyyah: keutamaan salat, puasa serta menghindari diri dari perbuatan dosa. Ganjaran surga bagi mereka yang patuh pada-Nya dan hukuman neraka untuk beberapa pendosa diselipkan dengan ayat serta hadis yang memperkuat pembahasan. Aa Gym mengangkat tema yang tidak sama. Bahkan juga, berkesan sepele, seperti menjaga hubungan baik dengan tetangga, memelihara keharmonisan dalam keluarga, atau kebersihan hati saat berbuat baik. Tetapi, tema-tema enteng seperti tersebut dalam kenyataannya disenangi oleh audiensnya serta membuat pendengar tausiyah Aa Gym merenungkan tindakannya.

Strategi beliau dalam menggapai efektivitas ceramah telah dimulai saat mengawali atau memberikan prolog dalam ceramah. Beragam pola yang ia gunakan dalam mengawali ceramahnya antara lain: mengawali ceramah dengan mengajukan sebuah pertanyaan sebagai bahan renungan; mengawalinya dengan gagasan besar tentang topik dan itu dianggap sebagai prolog, setelah itu beliau ungkap renungan-renungan sebagai koreksian terhadap perilaku yang tidak baik atau sebaliknya mengungkap keistimewaan dan keutamaan perilaku yang baik; mengawali ceramah dengan do'a yang cukup panjang; mengawali ceramah tampa prolog langsung ke pembahasan atau materi seperti ketika beliau menyampaikan ceramah tentang Membentuk Karakter Baik dan Kuat dalam Islam; mengawali ceramah dengan menggambarkan situasi atau keadaan yang umumnya dirasakan, 
dialami manusia, seperti dalam ceramahnya tentang Cara Menyikapi Belitan Masalah.

Beliau juga biasa menggunakan humor agar tingkat perhatian audience tetap terjaga. Humor bagi beliau merupakan bawaan materi ceramah, sebab humor yang beliau sisipkan tidak keluar dari materi yang sedang dibicarakan. Humor beliau lebih upaya beliau untuk mentertawakan diri masing-masing.

Gaya komunikasi dan retorika KH. Abdullah Gymnastiar secara utuh dapat diketahui dari ceramah-ceramahnya atau dakwah tutur. Ada banyak ceramah KH. Abdullah Gymnastiar yang terdokumentasikan.

KH. Aam Amiruddin. Pola tutur ceramah Aam Amirudin, intonasinya itu datar tidak meledak-ledak, tapi walaupun datar bukan berarti tidak ada variasi suara untuk membedakan maksud penyampaian. Uraian atau penjelasan sangat menyentuh, ril, kongkrit, relevan dengan pengalaman hidup keseharian. Selain itu pembahasannya utuh, tuntas dan argumentative.

Aam Amirudin memiliki gaya penyampaian dakwah yang khas dan mudah untuk dimengerti bagi pendengarnya. Pandangan beliau yang cukup moderat dan menggunakan berbagai dalil yang sesuai dengan kondisi kekinian dan sesuai dengan budaya Indonesia dan menjadi pilihan tepat bagi para mad'u . Disebutkan oleh Imron Rosyidi, Islam yang dibawakan oleh beliau mudah diterima oleh semua kalangan, dan terutama kalangan terdidik dan perkotaan. Ceramah beliau di radio Oz mencerminkan bahwa ceramah yang beliau sampaikan juga dapat diterima oleh kalangan muda.

Keunikan Dakwah ustad Aam Amirudin dalam setiap tingkah laku yang di lakukan saat berdakwah itu sangat perhatian karena cara berdakwah nya itu nyentrik,selain itu juga dalam ceramahnya itu tidak terlalu terkesan formal dan malah bengenre komedi di setiap tutur katanya.Jadi para mad'u yang mendengarkan ceramah paUstad.Aam Amirudin ini antusias dan tidak jenuh dalam ceramahnya.kalau kebanyakan para tokoh lain dalam gaya ceramahnya itu terkesan bosan atau beliau ini selalu memberikan kesan rame pada setiap sesi ceramahnya.

Tampaknya ustadz Aam Amirudin memiliki keunggulan dalam hal pemilihan kata dan dalam mencari isu yang menarik. Cara Ustadz Aam menjelaskan suatu topik, lebih banyak menggunakan pola penuturan dialogis, mengungkap pengalaman pribadi dalam perjalanan spiritual, mengusahakan memiliki pijakan yang kuat dari hadits Nabi Saw dan ayat al-Qur'an, serta pengibaratan hikmah ajaran secara kontekstual-dialogis dengan keadaan jama'ah yang didakwahi.

Beberapa contoh bukti penuturan dialogis yang dapat diperoleh dari ceramah-ceramahnya: Di awal ceramah ia menyampaikan prolog. Prolognya sedapat mungkin memiliki pijakan pada cara rasul dalam menyampaikan ceramah.

Keunikan lain dari ceramahnya adalah isu baru berkenaan dengan pemahaman agama. Salah satunya berkenaan dengan hal yang memasukan ke 
syurga. Bahwa yang memasukan ke syurga itu bukan karena amal melainkan karena rahmatnya. Ini menimbulkan kebingungan mustami', di saat seperti itu beliau masuk dengan penjelasan yang memberikan kepuasan.

Ustadz Aam sepertinya tahu apa yang akan membuat mustami'in merasa senang dari ceramah yang disampaikan. Dengan menggunakan kecerdasan logika untuk mengolah setiap informasi yang saling mendukung untuk menjalaskan topik yang dibahas, kadang bersifat jenaka, pengalaman sehari-hari dari model contoh perilaku baik atau sebaliknya. Kaitan dengan paparan yang mengandung jenaka, Ustadz Aam juga memiliki keunikan dari segi jenakanya, yakni berisi koreksi atau kritik terhadap kebiasaan umumnya manusia. Seakan mustami' atau hadirin diajak untuk mentertawakan kebiasaan-kebiasaan dirinya yang kurang patut dilakukan.

Kebiasaan beliau dalam memulai ceramah: mengawali ceramah dengan menyebutkan topik yang akan dibahas dan dilanjutkan dengan basa-basi; langsung kepada uraian; mengawalinya dengan pemikiran mendasar atau yang dapat mendasari topik; mengawali dengan nukilan ayat al-Qur'an maupun hadits yang dipilih Ustadz Aam karena dipandang sangat relevan dengan topik yang akan dibahas; langsung menyebutkan topik dan pembahasan; mengawali dengan sebuah renungan terhadap kenyataan yang terjadi beberapa waktu lalu, hal ini seperti ketika beliau ceramah tentang Pengaruh Game Online.; Mengawalinya dengan kalimat tanya,; Mengawalinya dengan menerangkan posisi topik dalam ajaran Islam.

Strategi untuk menjaga kadar perhatian jama'ah terhadap ceramah yang dilakukannya berupa pilihan kata (bahasa), hal ini bisa ditemukan dalam ceramahnya salah satunya "Peranan Keluarga sebagai Fondasi Ketahanan Bangsa”, antara lain analogi/ perumpamaan ibadah rumah tangga dengan ibadah shalat, menurutnya takbiratul ihramnya ibadah keluarga adalah mitsaqan ghalidhan, dan salamnya ibadah rumah tangga adalah kematian.

Gaya komunikasi dan retorika Ustadz H. Aam Amiruddin secara utuh dapat diketahui dari ceramah-ceramahnya atau dakwah tutur antara lain:

Tabel 2. Kemampuan Komunikasi

\begin{tabular}{cccc}
\hline Tokoh Da'i & Gaya Komunikasi & Retorika & Pilihan Bahasa \\
\hline $\begin{array}{c}\text { KH. Miftah } \\
\text { Faridl }\end{array}$ & $\begin{array}{c}\text { Campuran komteks } \\
\text { tinggi dan rendah, } \\
\text { Sesuai situasi } \\
\text { terkadang langsung, } \\
\text { tegas, tanpa basa } \\
\text { basi }\end{array}$ & $\begin{array}{c}\text { Upaya menerjemahkan } \\
\text { Islam dalam kehidupan }\end{array}$ & $\begin{array}{c}\text { Bahasa yang runtut dan } \\
\text { teratur, sistematis }\end{array}$ \\
$\begin{array}{c}\text { Konteks rendah, } \\
\text { Gymnastiar } \\
\text { tanpa basa basi, } \\
\text { langsung }\end{array}$ & $\begin{array}{c}\text { Penekanan pada } \\
\text { manifestasi dzikrullah, } \\
\text { penjabaran hakikat } \\
\text { dzikrullah dalam segala } \\
\text { lapangan kehidupan }\end{array}$ & $\begin{array}{c}\text { Ilustrasi-ilustrasi yang } \\
\text { menguatkan prinsip } \\
\text { dzikrullah }\end{array}$ \\
\hline
\end{tabular}




\begin{tabular}{|c|c|c|c|}
\hline & & $\begin{array}{l}\text { Dzikrullah sebagai jalan } \\
\text { kesuksesan dan solusi } \\
\text { atas beragam masalah }\end{array}$ & \\
\hline $\begin{array}{c}\text { Ust. H. Aam } \\
\text { Amirudin }\end{array}$ & $\begin{array}{l}\text { Basa basi, tidak } \\
\text { langsung }\end{array}$ & $\begin{array}{c}\text { Perspektif } \\
\text { dakwah/pendidikan yang } \\
\text { memadukan Islam dan } \\
\text { dunia modern }\end{array}$ & $\begin{array}{c}\text { Penggunaan ilmu social } \\
\text { modern } \\
\text { Penggunaan wawasan } \\
\text { kontemporer }\end{array}$ \\
\hline
\end{tabular}

Tabel 2 menggambarkan gaya komunikasi yang ditunjukkan oleh sosok KH. Miftah Faridl tampaknya lebih menyerupai perpaduan antara konteks tinggi dan rendah. Gaya komunikasi konteks tinggi tampak atau terasa ketika beliau mengemukakan sebuah gagasan yang dapat berdampak secara social.Misalnya ketika beliau harus memberikan tanggapan terhadap ekspresi muslim berkenaan dengan sikap barat dalam menistakan Nabi Muhammad Saw. Gaya komunikasi konteks tinggi juga terkadang tampak ketika beliau harus menunjukkan sikapnya atas fenomena keragaman atau perbedaan dikalangan umat Islam, misalnya beliau bersikap arif kepada kelompok yang berbeda dengan dirinya seraya berkata, "Kita boleh tidak sependapat terhadap cintanya Rabi'ah, tapi ajarannya tentang syair ungkapan yang tahu diri ..itu sangat bagus kita pedomani.

Namun pada kesempatan lain tampak beliau tidak basa basi terutama berkenaan dengan praktik ibadah mahdhah bahkan termasuk ibadah dzikrullah ba'da shalat. Beliau berkata: “...kita dahulukan apa yang telah dicontohkan Nabi Saw sebab tentu ada hikmah di balik itu, setelah yang pokok kita tunaikan ..silahkan saja berdzikir mau berapapun jumlahnya.

Berbeda dengan KH. Miftah Faridl, KH. Abdullah Gymnastiar, gaya tutur beliau sangat praktis dan sederhana. Kendati uraiannya tentang satu ajaran mesti diberikan ilustrasi yang banyak terkesan bahwa audience harus betul-betul diyakinkan. Penuturan beliau tentang ajaran sangat praktis, misalnya ketika beliau menjelaskan kiat-kiat atau tips menjalani hidup dengan penuh ketenangan.

Berbeda dengan dua tokoh sebelumnya Aam Amirudin bahkan menggunakan penuturan ilmiah modern untuk menjelaskan Islam. Dalam beberapa hal beberapa kebiasaan yang salah dikoreksi dan beliau mencoba memberikan pelurusan dan pandangan berdasarkan sudut pandang ilmiah modern. Gaya komunikasi beliau lebih kepada gaya komunikasi konteks tinggi.

\section{Konsteks Situasi (Situation Context)}

Konteks situasi yang menyertai ketiga tokoh dapat digambarkan dengan table di bawah. Berdasarkan teori karismatik Weber (Efley, 2015), konteks social dan tawaran perilaku sebagai solusi merupakan sebagian dari penentu diterimanya sosok pendakwah oleh masyarakat. Kerelaan diri berkorban untuk memperhatikan nasib umat merupakan ciri altruistik, cermin kepekaan terhadap situasi (Saidil Mustar, 2015). Inilah daya penerimaan ketiga tokoh yang dapat digambarkan sebagai berikut: 
KH. Miftah Faridl. Konteks social sosok KH. Miftah Faridl dapat dijelaskan sebagai pemahaman beliau sebagai pendakwah tentang gejala memudarnya pembinaan keagamaan yang berdampak pada terkikisnya daya rekat agama dalam kehidupan. Salah satu bentuk kegerahan beliau terhadap kondisi ini munculnya dorongan untuk menghadirkan kembali ajaran Islam sebagaimana tercantum dalam al-Qur'an dan al-Hadits dalam bentuk yang koheren dengan kebutuhan manusia di sepanjang zaman.

Dikemukakan oleh Karsidi Diningrat, Ketua Umum Al-Jami'iyyatul Washliyyah Jawa Barat, beliau ini sosok pendakwah pada level akademisi. Tapi beliau punya prinsip yang kuat dalam pengamalan agama misalnya tentang dzikir. Katanya menurut beliau dzikir bada shalat itu pertama harus ikuti ketentuan dari Rasul yaitu subhanallah 33 kali, Alhamdulillah 33 kali dan allahu akbar 33 kali, dan ditutup dengan tahlil lailaha illallah satu kali setelah itu berdo'a, baru setelah do'a silahkan berdzikir sesuai kehendak mau ratusan kali atau bahkan ribuan kali.Retorika pa Miftah Faridl itu memang tidak meledak-meledak, tenang, datar.

KH. Abdullah Gymnastiar. Sosok KH. Abdullah Gymnastiar muncul ditengah kondisi masyarakat yang umumnya memiliki kegersangan secara spiritual. Masyarakat butuh model dalam spiritualitas yang dikembangkan dalam pendekatan tasawuf. Kendati tasawuf bukan barang baru dalam percaturan kehidupan muslim, namun bagi masyarakat yang belum banyak mengenyam atau minus dalam hal pemenuhan kebutuhan agama, maka gaya dan pendekatan yang diperkenalkan Aa Gym ini seakan menjadi solusi atas kekosongan rasa keberagamaan mereka.

Tingginya minat masyarakat terhadap gaya dakwah Aa Gym menjadi bukti bahwa gaya khas model Aa Gym ini benar-benar disukai masyarakat. Pesan-pesan yang keluar dari lisan dari Aa Gym seakan mengandung mukjizat atau kehebatan, membuat telinga masyarakat selalu merindukannya. Dan efek ketenangan, kenyamanan dan rasa betah ketika mereka berkumpul atau hadir dalam majlis pengajian yang diselenggarakan oleh Aa Gym.

Dikemukakan oleh Ketua Jami'ayyatul Washliyah Jawa Barat, H. Karsidi Diningrat, yang tampak dari Aa Gym itu kesederhanaannya, sederhana dalam bertutur atau berkomunikasi, namun di balik kesederhanaan ia mempunyai kelebihan. Kelebihan yang ia memiliki sangat mengetahui pasar atau selera dan kebutuhan pasar. Beliau sangat sederhana tapi beliau mampu berbicara tentang banyak hal, tentang bisnis, pergaulan di tengah komunitas beragam.

KH. Aam Amiruddin. Konteks sosial Ustadz Aam Amirudin dapat dijelaskan sebagai pemahaman beliau sebagai pendakwah terhadap tantangan kemajuan teknologi komunikasi dan efek yang dapat merusak generasi. Disadari betul bahwa kemajuan teknologi sedemikian pesat. Generasi yang hidup atau terlahir era sebelum tahun 1970-an dikenal sebagai "x" generation, sementara itu mereka yang terlahir pada kurun tahun 1980-an sebagai generasi millennia. Hidup serba di genggaman tangan. Mereka berkomunikasi, mencari informasi, dan 
menikmati hiburan cukup dengan menggerakan jari tangan mereka. Kondisi ini dapat merupakan satu kenikmatan tapi sekaligus menjadi tantangan. Sebab tidak sedikit pengaruh negative menjadi tumbuh subur gara-gara media tangan tersebut. Berbagai perilaku patologis banyak terjadi pada kalangan manusia yang hidup pada generasi millennia itu.

Alternatif perilaku dan pendekatan dakwah Ustadz Aam yaitu menjadikan trend kehidupan era millennia baik penggunaan media maupun adaptasi budaya kontemporer untuk digunakan sebagai cara dan tujuan yang positif, misalnya untuk mempercapat proses belajar al-Qur'an, menggali pemahaman agama, ngaji tafsir dan seterusnya. Juga menjadikan media sebagai sarana bersilaturahmi, sebab pesan-pesan keagamaan yang positif dapat disampaikan atau disebarluaskan dengan memanfaatkan kehadiran teknologi komunikasi.

Aam Amirudin menampilkan wajah Islam yang berkarisma, elegan, dan modern. Untuk mengetahui seperti apa model dakwah Aam ini dapat ditelusur ke pusat informasi yayasan Percikan Iman. Yayasan ini sendiri muncul sebagai langkah solutif bagi generasi Qur'ani. Bahwa sebagai bagian dari aktivitas muslim kesannya positif, maju, modern, kreatif, terampil dan atribut positif lainnya.

Berdasarkan perspektifnya tentang kemajuan zaman, bentuk kreativitas dakwah Ustadz Aam cukup variatif. Visi dakwah Ustadz Aam Amirudin yaitu menuju era dakwah tanpa batas. Wujud aplikasi dakwah menuju era dakwah tanpa batas ini dapat dilihat dari geliat, kiprah dakwah

Tabel 3. Konteks Situasi Da’i Karismatik

\begin{tabular}{|c|c|c|}
\hline Da'i & $\begin{array}{c}\text { Situasi krisis/ } \\
\text { Masalah }\end{array}$ & Solusi \\
\hline $\begin{array}{l}\text { KH. Miftah } \\
\text { Faridl }\end{array}$ & $\begin{array}{l}\text { Memudarnya pembinaan } \\
\text { keagamaan yang berdampak } \\
\text { pada terkikisnya daya rekat } \\
\text { agama dalam kehidupan }\end{array}$ & $\begin{array}{l}\text { Menghadirkan kembali ajaran Islam } \\
\text { sebagaimana tercantum dalam al- } \\
\text { Qur'an dan al-Hadits dalam bentuk } \\
\text { yang koheren dengan kebutuhan } \\
\text { manusia di sepanjang zaman }\end{array}$ \\
\hline $\begin{array}{l}\text { KH. Abdullah } \\
\text { Gymnastiar }\end{array}$ & $\begin{array}{c}\text { Kegoncangan psikhis akibat } \\
\text { tawaran prinsip moral yang } \\
\text { tidak jelas serta kegersangan } \\
\text { spiritualitas }\end{array}$ & $\begin{array}{l}\text { Tawaran menjalani praktik hidup } \\
\text { yang penuh dengan nuansa } \\
\text { dzikrullah, keajaiban dzikrullah }\end{array}$ \\
\hline $\begin{array}{l}\text { Ust. H. Aam } \\
\text { Amirudin }\end{array}$ & $\begin{array}{l}\text { Tantangan kemajuan } \\
\text { teknologi komunikasi dan } \\
\text { efek yang dapat merusak } \\
\text { generasi }\end{array}$ & $\begin{array}{l}\text { Menjadikan trend kehidupan era } \\
\text { millennia baik penggunaan media } \\
\text { maupun adaptasi budaya } \\
\text { kontemporer secara positif }\end{array}$ \\
\hline
\end{tabular}

Berdasarkan tabel 3 presentasi dakwah para tokoh itu menunjukkan dua tampilan: tampilan muka dan tampilan belakang. Tampilan depan dikenal ketika mereka melakukan tugas dakwah/ceramah. Umumnya para tokoh dakwah memiliki kelebihan luar biasa dalam memilih dan mengemas pesan dakwah. Pesan 
dakwah yang mereka sampaikan umumknya enak didengar, mudah dimengerti maksud dan tujuannya, serta isinya dapat diterima sebagai pesan kebenaran ajaran Islam. Namun demikian seringkali kesimpulan tentang tampilan depan itu berbeda dengan tampilan belakang, terutama ketika diukur sejauhmana kebenaran apa yang disampaikan juga diimplementasikan olehnya sebagai pendakwah.

Sebuah pandangan diberikan oleh seorang akademisi, Dosen UIN Bandung, Asep Saepul Rohim, umumnya para pendakwah itu bagus saat mereka menyampaikan pesan dakwah, kreativitas penyampaian pesan, pemilihan contoh dan ilustrasi serta pengaturan volume suara saat melakukan ceramah, namun yang sering ditemukan pada sosok para pendakwah itu ditemukan lain ketika mengamati kehidupan mereka dalam pergaulan sehari-hari. Tampaknya rahasia keburukan sifat dan tabe'at para da'i itu ditutupi oleh Allah SW'T. Hanya saja kadarnya barangkali agak berbeda dengan manusia pada umumnya, mereka tidak seburuk manusia pada umumnya, dalam beberapa masih memiliki daya control untuk mengendalikan perilakunya, paling tidak mereka paham siapa dirinya, apa yang harus mereka jaga agar citra dirinya sebagai pendakwah tidak menjadi hancur.

\section{PENUTUP}

Profil ketiga sosok da'i karismatik: KH. Miftah Faridl, KH. Abdullah Gymnastiar dan Ustadz H. Aam Amirudin, memiliki latar pengalaman pendidikan keagamaan yang sangat kuat, semuanya pernah mengenyam pendidikan pesantren seperti Ustadz Aam pernah mengikuti kegiatan pesantren di Pesantren Persatuan Islam, dan berlanjut ke LIPIA. Aa Gym, beliau pernah mengikuti pesantren di Pesantren Miftahul Khoer Tasikmalaya. Sementara itu KH. Miftah Faridl memiliki latar pendidikan pesantren Muhammadiyah. Selain itu mereka juga memiliki pengalaman studi ilmu social modern seperti Aam Amirudin S2 dan S3 nya diselesaikan dalam bidang ilmu komunikasi. Sementara itu KH. Miftah Faridl menyelesaikan studinya dalam Ilmu Dakwah, dan Aa Gym lebih menyukai menggali hikmah dari pengalaman.

Mutu personal dan kepribadian sosok da’i karismatik seperti KH. Miftah Faridl, KH. Abdullah Gymnastiar dan Ustadz H. Aam Amirudin, dapat diidentifikasi menyangkut aspek trust, integrity, honesty maupun consistency. Ketiga tokoh tersebut memiliki integritas, kepercayaan dan konsistensi. Ketiga tokoh tersebut hingga kini tetap berdakwah dan tetap menyuarakan prinsip kebenaran.

Kemampuan komunikasi efektif ketiga sosok da'i karismatik : KH. Miftah Faridl, KH. Abdullah Gymnastiar dan Ustadz H. Aam Amirudin, dapat ditemukan dalam tiga aspek yaitu gaya komunikasi, retorika dan pilihan bahasa. Pertama, gaya komunikasi KH. Miftah Faridl lebih memiliki corak campuran konteks tinggi dan rendah. Retorika beliau, tuturan sistematis dalam menerjemahkan Islam dalam kehidupan. Sementara itu pilihan bahasa runtut, teratur, sistematis dengan 
tingkatan bahasa dapat diterima oleh kalangan masyarakat mengah ke atas. Kedua, gaya komunikasi KH. Abdullah Gymnastiar lebih memiliki corak sederhana dan praktis lebih memiliki ciri konteks rendah. Ketiga Gaya komunikasi Ustadz Aam Amirudin lebih memiliki corak tidak langsung atau konteks tinggi. Retorika beliau lebih menggunakan perspektif dakwah/pendidikan yang memadukan Islam dan dunia modern. Sementara pilihan bahasa tampak pada warn komunikasi yang menunjukkan penggunaan ilmu social modern atau penggunaan wawasan kontemporer.

Konteks social yang mengantarkan sosok da’i karismatik KH. Miftah Faridl, KH. Abdullah Gymnastiar dan Ustadz H. Aam Amirudin sehingga menjadi panutan masyarakat. Pertama KH. Miftah Faridl, diketahui dari pandangan tentang memudarnya pembinaan keagamaan yang berdampak pada terkikisnya daya rekat agama dalam kehidupan, solusi yang ditawarkan menghadirkan kembali ajaran Islam sebagaimana tercantum dalam al-Qur'an dan al-Hadits dalam bentuk yang koheren dengan kebutuhan manusia di sepanjang zaman. Kedua, KH. Abdullah Gymnastiar dapat dikenali dari pandangannya tentang kegoncangan psikhis masyarakat akibat tawaran prinsip moral yang tidak jelas serta kegersangan spiritualitas. Solusi yang beliau tawarkan menjalani praktik hidup yang penuh dengan nuansa dzikrullah, keajaiban dzikrullah. Ketiga, Ustadz Aam Amirudin dapat dikenali melalui pandangannya tentang tantangan kemajuan teknologi komunikasi dan efeknya yang dapat merusak generasi. Solusi yang beliau tawarkan, menjadikan trend kehidupan era millennia baik penggunaan media maupun adaptasi budaya kontemporer secara positif.

\section{DAFTAR PUSTAKA}

Aripudin, A. \& Mudhofir. (2014). Perbandingan Dakwah. Bandung: PT. Remaja Rosda Karya.

Augustia, M. (2016). Analisis Dramaturgi pada Self-Presentation Presenter Program Oshop di OChanel. Jurnal Ilmiah Universitas Bakrie, (4)1,

Efley, J. L., (2015). Weber's Theory of Charismatic Leadreship: The Case of

Muslim Leaders in Contemporary Indonesians Politics. International Journal of Humanities and Social Science. 5(7) July 2015.

Mulyana, D. 2008. Komunikasi Efektif, Cetakan ketiga. Bandung: Rosdakarya.

Mustar, S. (2015). Kepribadian Da'i dalam Berdakwah. Jurnal Tarbiyah, (22)1, 87-113.

Nitin, P. B. (2017). Analisis Gaya Komunikasi Ahmad Faiz Zainudin. eJournal Ilmu Komunikasi, (5)3, 376-387.

Refdian. (2013). Analisis Deskriptif Gaya Komunikasi Ustadz Sholeh Mahmud dalam Berdakwah. Jakarta: Fakultas Ilmu Dakwah dan Ilmu Komunikasi UIN Jakarta.

Rifanudin, A. (2007). Etika Tabligh. Bandung: PRD Fakultas Dakwah dan Komunikasi. 
Hajir Tajiri

Haris H. dan Fikroh S. (2011). Hubungan Antara Tingkat Preferensi Kepada Komunikator Dakwah dengan Perilaku Beragama Jamaah Pengajian H. Aam Amiruddin dan Hj. Farida Fausy di Kota Bandung. Prosiding SnaPP, 139-147.

Ma'arif, B. S. (2010). Pola Komunikasi Dakwah KH. Abdullah Gimnastiar dan KH. Jalaluddin Rakhmat, MIMBAR Jurnal Sosial dan Pembangunan, 25(2) (JuliDesember 2009) 